\title{
Sequel as A Type of Metatext Practice: Philosophical Perspective
}

\section{La secuela como tipo de práctica de metatexto: perspectiva filosófica}

Natalia Vladimirovna Khorosheva

Perm State National Research University, Russia

https://orcid.org/0000-0003-4564-9973

\author{
Alyona Vladimirovna Kostyrya \\ Perm State National Research University, Russia \\ https://orcid.org/0000-0002-6510-3911 \\ Natalya Vasilyevna Mamonova \\ Chelyabinsk State University, Russia \\ https://orcid.org/0000-0002-3368-3632 \\ Olga Vasilyevna Lysova \\ Bashkirsky State University (Birsk Branch), Russia \\ https://orcid.org/0000-0002-8421-9012 \\ Natalia Sergeevna Popova \\ Perm State Humanitarian Pedagogical University, Perm, Russia \\ https://orcid.org/0000-0001-8519-7735
}

\section{*Correspondencia}

Email: romanphyl@gmail.com

\section{Citar como:}

\footnotetext{
Vladimirovna, N., Vladimirovna, A., Vasilyevna, N., Vasilyevna, O., \& Sergeevna, N. (2021). Sequel as A Type of Metatext Practice: Philosophical Perspective, Propósitos y Representaciones, 9(SPE2), e1105. http://dx.doi.org/10.20511/pyr2021.v9nSPE2.1105
} 


\section{Summary}

The article considers the phenomenon of the sequel as a type of metatext practice and as an integral component in the chain of knowledge transfer. The reproducibility of the original text is thus correlated with "unlimited" semiosis / interpretation. The phenomenon of metatext is closely related to the functioning of secondary texts, since any metatext belongs to the category of secondary texts. By secondary, we mean text created as a result of processing the original, primary text.The sequel acts as a secondary text, and the text that interprets the main text. The relevance of the research, therefore, is related to such philosophical and linguistic problems as reference and interpretation. The popularity of sequels written by modern authors to Jane Austen's novels can be seen as a particular manifestation of the general "fashion" for secondariness. Consciously or not, modern "successors" of her novels tend to repeat her style, even if they simply borrow the characters and plot of the novels. Within the framework of semiotics, the sequel can be considered as a "sign" that displays its referent - the novels of Austen. However (from the point of view of stylistics), the sequel cannot be an exact copy of its original, since it is invariably created in other socio-cultural conditions. A sequel as a sign can display its referent (novel) in three main types: index, icon, symbol, and their combinations. Thus, the article analyzes each of the ways of display and concludes that it is impossible to symbolically reflect the proto-text on the example of the novel "Pride and prejudice" and its sequels written by contemporary authors. One of the results of the work is the assumption that the ontological status of the new "possible world" in the sequel and therefore its communicative success, are in direct correlation with the way of referential representation of the original.

Keywords: sequel, semiosis, referent, metatext, secondary text, metatext practice, Jane Austen.

\section{Resumen}

El artículo considera el fenómeno de la secuela como un tipo de práctica del metatexto y como un componente integral en la cadena de transferencia del conocimiento. La reproducibilidad del texto original se correlaciona así con la semiosis / interpretación "ilimitada". El fenómeno del metatexto está íntimamente relacionado con el funcionamiento de los textos secundarios, ya que cualquier metatexto pertenece a la categoría de textos secundarios. Por secundario, nos referimos al texto creado como resultado del procesamiento del texto primario original, la secuela actúa como un texto secundario y el texto que interpreta el texto principal. La relevancia de la investigación, por tanto, está relacionada con problemas filosóficos y lingüísticos como la referencia y la interpretación. La popularidad de las secuelas escritas por autores modernos de las novelas de Jane Austen puede verse como una manifestación particular de la "moda" general de la secundaria. Conscientemente o no, los "sucesores" modernos de sus novelas tienden a repetir su estilo, incluso si simplemente toman prestados los personajes y la trama de las novelas. En el marco de la semiótica, la secuela puede considerarse como un "signo" que despliega su referente: las novelas de Austen. Sin embargo (desde el punto de vista estilístico), la secuela no puede ser una copia exacta de su original, ya que invariablemente se crea en otras condiciones socioculturales. Una secuela como signo puede mostrar su referente (novela) en tres tipos principales: índice, icono, símbolo y sus combinaciones. Así, el artículo analiza cada una de las formas de exhibición y concluye que es imposible reflejar simbólicamente el proto-texto sobre el ejemplo de la novela "Orgullo y prejuicio" y sus secuelas escritas por autores contemporáneos. Uno de los resultados del trabajo es el supuesto de que el estatus ontológico del nuevo "mundo posible" en la secuela y por tanto su éxito comunicativo, están en correlación directa con la forma de representación referencial del original.

Palabras clave: secuela, semiosis, referente, metatexto, texto secundario, práctica del metatexto, Jane Austen.

\section{Introducción}

According to the "Theory of communicative action" by J. Habermas (2001), "the process of ontogenetic evolution of the language personality $\leq \ldots \geq$ is expressed in the formation 
of the ability of homo loquens to generate and understand texts" (Bagautdinov et al., 2018, p. 38). From a semiotic point of view, culture can be considered as "the sum of texts and their associated set of functions, or as a device that generates these texts" (Lotman, 2000, p. 517). Thus, the function of generating texts allows culture to exist as a collective memory - storing and processing information. The statement that the semiotic structure of culture and the semiotic structure of memory are functionally similar phenomena does not contradict the status of culture as a dynamic system. According to representatives of the Tartu-Moscow scientific school, culture simultaneously records past experience and acts as a program for the production of new texts (Lotman, 2000, p. 517). From the point of view of semiotics, culture acts as a device for creating and producing texts. Therefore, there must also be an algorithm by which this "production" is carried out. The use of the concept "metatext practice" is one of the ways to describe this algorithm, i.e., the semiotic mechanism of the birth of secondary texts in the cultural space. The purpose of this section is to define this mechanism, since its analysis in our study allows us to determine the ontological status of the sequel. The relevance of the research is connected with the consideration of the concepts of metatext and sequel in the framework of the theory of semiosis - as a sign of its referent, as well as in the framework of the theory of secondary texts, as processing of the source text. For the first time, writing a sequel is considered as a cognitive-semiotic mechanism of displaying the original work (proto-text). The material for the study is Jane Austen's novel "Pride and prejudice" (Austen, 2010) and its sequels written by contemporary authors: Colin McCullough - "Independence of Mary Bennet" (2008), Jane Dawkins - "Letters from Pemberley" (2003), Laura Lillian - "Rainy days" (2009). Methodologically, the article fits into modern research on text semiotics and linguistics (Chandler, 2007; Stockwell, 2013). The principle of system-structural description is used as the main research method.

\section{Main part}

The text, according to Lotman, is "the fundamental concept of modern semiotics, the primary element of the basic unit of culture". Thus, in culture, in contrast to linguistics, text can be understood as a "primary" element that functions as a relatively autonomous integral sign (Lotman, 2000, p. 508). Some scholars also perceive texts "as containers full of meanings to be extracted" (Karamalak, 2017).

Lotman's idea that "the place of a text in a text space is defined as the relation of a given text to a set of potential texts" (Lotman, 2000, p. 514) means that each text has a potential that can be "reflected" by the set of derivative texts surrounding it. Thus, the text as a basic unit of culture is characterized by reflexivity. The problem of reflection as a phenomenon of selfknowledge occupies a special place in humanitarian research. Reflexivity, understood as the ability of a language to describe itself, is directly related to metatext practice.

Metatext is a concept of modern linguistics, semiotics, literary studies, and cultural studies. However, the problem of metatext has been considered primarily in the framework of the general philosophical approach, according to which metatext is a form of expression of transtextual connections: for example, in the linguistics of a text, metatext defines texts that arise about or as a result of understanding other texts. Metatext in literary studies is "a text addressed not only to the subject, but also to the author's word about it", in which, according to Lotman, "the object of the image becomes the literary image itself" (Lotman, 2003, p. 339). Metatext is also understood as "or secondary derivative literary activity, including allusions, loanwords, imitations, paraphrases, commonplaces, and many other cases of literary dependence" (Spirik, 2014, p. 33). In addition, "the trend towards expanding the scope of the metatext category has recently been presented in various works on pragmalinguistics" (Witosz, 2017). 


\section{Metatext practice}

If we consider the entire number of texts created as a "response" to the source text as a single text field, then metatextual practice will be understood as a process of expanding this "field" by rethinking and reworking the source. Therefore, by metatext practice, we mean the practice of creating metatexts. The phenomenon of metatext is closely related to the functioning of secondary texts, since any metatext belongs to the category of secondary texts. By secondary text, we mean text created as a result of processing the original, primary text.

As part of our work, it is important to note that classic works (Jane Austen's novels) are a kind of reservoir for modern literature, from which many writers draw inspiration for creating secondary texts: sequels, stylizations, and works of fan fiction. The reasons for the popularity of secondary texts are the following factors: the focus of modern culture on serial forms (Eco, 1997), the game use of classical heritage (intertext from narrative fragments; mosaic of styles, genre forms, hoaxes, false quotes, references to non-existent authors (Chernyak, 2012, p. 237). An equally important reason is also the persistent fashion for classics, which is associated, according to researchers, "with the weariness of readers from the obvious rudeness of modern life" (Troost, 2001, p. 4).

\section{Sequels to Jane Austen novels}

The Cambridge dictionary defines sequel as "a book, movie, or play that continues the story of a previous book, etc."(Cambridge Dictionary, URL). Most researchers understand a sequel as "a continuation of the novel, when the plot and characters from the finished novel are extracted for development in new adventures $\leq \ldots \geq$ after the end of the source text's narrative time" (Parey, 2018, p. 9). The phenomenon of sequel in modern mass literature is of great interest for literary and linguistic research for a number of reasons. First, the concept of sequel is widely used in various areas of popular culture, since a sequel can continue the storyline of not only a book or movie, but also a computer game. The sequel, therefore, is an integral component of the modern mass consciousness. Directly in literature, the sequel is known since the writing of Virgil's "Aeneid", "continuing" the "Iliad" and "Odyssey" of Homer (Franke, 2013). Having such "deep roots", the sequel organically fit into modern everyday culture and firmly occupied its niche in the literary market (Percec, 2020). A number of researchers explain this by the tendency to "clip thinking" that arose at the end of the last century and the subsequent "literary default".

On the other hand, the sequel, being "secondary" in its essence, always translates a certain part of the classical heritage, translating the language of elite culture into a more standardized, understandable for the "non-philological" public. Consequently, sequel as a genre serves as an intermediary, being a link in the chain of knowledge and information transfer, which is consistent with the idea of $\mathrm{M}$. Yu. Lotman about culture / cultural texts as a "transmitting device" (Lotman, 1993). The sequel thus is definitely a dynamic phenomenon (genre), a translator of "classical knowledge", especially if the original text is a classic novel.

This is the case with the writing of sequels to Jane Austen's novels, which are rightfully considered the "Golden Fund" of English literature on a par with the legacy of W. Shakespeare and C. Dickens (Breuer, n.d.). Interest in her literary heritage began at the beginning of the twentieth century, then was strengthened by the General commercialization of art in the second half of it, and has reached a high point in our days with the appearance of film adaptations of her novels and the emergence of online communities and fan clubs (Hopkins, 2018; Wifall, 2010). The attitude towards Jane Austen in her native England was changing from oblivion to a truly national love. However, these days, not only her work, but also her biographies, that is, she herself as a person, her family, are of great interest, both for compatriots and for the global readership (Gabrielle, 2015). 
Since the sequel as a literary continuation refers to secondary texts, it can thus be considered as a type of metatext practice. The reflexive nature of the sequel is already in the very essence of its creation - since it always occurs as a reaction to the original work.

There are several types of sequels: some are "written for enthusiastic reasons to prolong the existence of the heroes of cult books", and others are commissioned by publishers "who seek to squeeze all possible benefits from brands". It is not surprising that "the literary community and the qualified reading minority, as a rule, treat sequels ironically or sharply negatively" (Chuprinin, 2007, p. 352). And, although the problem of second-handedness in culture and literature, in particular - is far from new, it was at the turn of the XX-XXI centuries, that "art and philosophy $\leq \ldots \geq$ extremely problematized the situation" (Bagdasarian, 2013, p. 102).

In order to examine the phenomenon of metatextuality, we will address issues related to the semiotic mechanism of secondary texts birth and their representational potential. Being universal, the general mechanism of semiosis (a sign exists only if it interprets another sign and thus becomes the object of interpretation for the next sign) is also applicable to the description of secondary texts. The metatext mechanism, therefore, can be described within the framework of semiosis, when each text is a consequence of the display of the previous text and at the same time a referent for the birth of the next. As with any sign, every piece of writing exists only in connection with its referent. Thus, if we consider any secondary text (a sequel) as a sign, then the primary text (a novel by Austen) will be perceived as its referent.

\section{Representative potential of sequels}

Any sign can display a referent in three main types: index, icon, symbol, and their combinations. An index is a "material label on a material referent", since it is impossible to indicate the unobservable (Brazgowska, 2018, p. 44). In the context of the metatext phenomenon, an index is an indication of the preceding text and a reference to it. Indexes are also used to localize an utterance (text) in time and space. An example of this type of display is spatial-temporal indexes, which allow the reader to identify time and place in the narrative, epoch, cultural realities, etc. For this reason, the reproduction of index signs of the original novel is highly desirable for the authors of sequels: while preserving their system (spatial and temporal localizers and other types of deictic), the sequel reproduces the same model of the textual picture of the world as in the original novel. So, for example, the sequel of the modern author Jane Dawkins, "Letters from Pemberley: 1814-1819: A Further Continuation of Jane Austen's Pride and Prejudice" (Dawkins, 2003) written to "Pride and prejudice" (Austen, 2010) is full of index marks indicating the reference situation reproduced in the text - the nineteenth century, Regent's England. The text mentions the writer Walter Scott, Jane Austen herself and her novels "Sense and sensibility", "Mansfield Park", and the Prince Regent. In addition to personals, the Austen era indexes include the names of London clubs (Almax), parks (Vauxhall), shops (Gunter's pastry shop), and so on.

The second type of display of the referent is by means of icons. Icons display the essential features of their referent, allowing you to "recognize" it. Portrait description, landscape - all these are examples of an iconic display. Iconic reproduction in the case of secondary texts concerns the style of the primary text, its storyline, and narrative tools. The display of the referent type of the icon is divided in turn in two ways: the icon-scheme and icon-image. Displaying the original text by the type of icon-scheme is not identical to the original in terms of style, and is a partial reproduction of the author's idiosyncrasy. In this case, for example, only certain realities and personalities of the original novel can be mentioned, or the author's stylistic means for updating characters can be partially used. For example, in the sequel "Independence of miss Mary Bennet" (McCullough, 2008), the author, Colin McCullough, borrows the characters from the novel "Pride and prejudice", but uses different stylistic tools to actualize them in the narrative. 
If the image is displayed as an icon, the authors of secondary texts try to reproduce the style of the original exactly, or at least get close to it. A positive attitude to the text in the case of its display by the type of icon-image, allows you to identify such works as stylizations to Austen. These include the novel "Rainy Days" by Laura Lilian (2009), which received numerous positive reviews from readers. Among the advantages of the work is the preservation of the "original" relationship between the main characters: Elizabeth Bennet and Mr. Darcy.

Theoretically, sequels can reproduce the text world of Jane Austen using a symbol. However, practice shows that a symbolic reading of the original is not typical for sequels. Modern anthropological research, for example, can use the name Austen as a concept or cultural sign (Fox, 2004), but sequels are usually a continuation of the original, and therefore should rather iconically reproduce the manner of writing Jane Austen.

The representative mechanism of sequels is, first of all, the display of the primary text by the type of icon reproduction of the original: as an icon-scheme or icon-image. But since the index component is always included in the reproduction of the spatial-temporal framework of the work, the sequel is characterized by an index-iconic type of display: index-iconic as a scheme and index-iconic as an image (this applies to the style, narrative, locus, descriptions.)

\section{Conclusion}

Our conclusion that the secondary text, ideally, should appear as an iconic sign of the primary text, reproducing the most characteristic features of the author's style, corresponds to the fact that modern sequels, as a rule, reproduce the world of Jane Austen's texts on an iconic model. This is what allows the reader to perceive the sequel as a "continuation", as if written by the author's hand. But "the text (in contrast to language as a system of means) can never be fully translated, because there is no potential unified text of texts" (Bakhtin, 1979, p. 285). Therefore, on the other hand, according to the theory of semiosis, the sequel as a sign of the original can not be its absolute icon, since it inevitably reflects the original from the point of view of the creator of the sequel, his or her cultural context. And this fully applies to the experience of creating sequels to Jane Austen's novels by modern authors. Some of them are more successful, and their work can be attributed to the type of sign "icon-scheme" (reproducing individual features of its referent), but most of the metatext only remotely resemble the original. Therefore, index iconism is the initial stage of the referent's representation, which, becoming more complex, can develop to the level of "icon-scheme". From a philosophical point of view, the referential mechanism of displaying the text-basis through the icon-image gives the text of the sequel the most "stable" ontological status - since the reader of the sequel is always focused on the continuation of the novel, which could have been written by Austen herself.

\section{Referencias}

Austen, J. (2010). Pride and prejudice. London: Collins Classics.

Bagautdinov, A. Minkin, M. Ivanov, A. Nizameeva, A. (2018). Language as a constructor of social and cultural reality. XLinguae, 11, 33-42.

Bagdasarian, O. (2013). Secondary forms in modern drama: strategies for transforming classics ("Reading the map by touch" by D. Bavilsky — "The Cherry orchard is sold?" by N. Franko). In: Toronto Slavic Quarterly, 44, 101-111.

Bakhtin, M.M. (1979). Esthetics of verbal creativity. Moscow: Iskusstvo.

Brazgowska, E.E. (2018). In the maze of semiotics. Moscow-Ekaterinburg: Armchair scientist.

Breuer, R. (n.d.). Jane Austen etc. An Essay on the Poetics of the Sequel. Retrieved from: http://webdoc.sub.gwdg.de/edoc/ia/eese/breuer/essay.html

Chandler, D. (2007). Semiotics. The basics. New York: Routledge.

Chernyak, M.A. (2012). Philological game as a strategy of prose of the XXI century. In: Yaroslavl pedagogical Bulletin, 1, I (Humanities), 236-240.

Chuprinin, S.I. (2007). Russian literature today. Moscow: Vremya. 
Dawkins, J. (2003). More Letters from Pemberley: 1814-1819: A Further Continuation of Jane Austen's Pride and Prejudice. Bloomington: iUniverse.

Eco, U. (1997). Reading Eco: An Anthology. Bloomington: Indiana University Press.

Fox, K. (2004). Watching the English. The hidden rules of English behavior. London: Hodder.

Franke, W. (2013). The secondariness of Virgilian epic and its unprecedented originality. College Literature, 40(1), 11-31.

Gabrielle, M. (2015). Fan Phenomena: Jane Austen. Bristol: Intellect Ltd.

Habermas, J. (2001). Moral Consciousness and Communicative Action. Saint Petersburg: Nauka.

Hopkins, L. (2018). After Austen. Reinventions, Rewritings, Revisitings. London: Palgrave Macmillan.

Karamalak, O., Pesina, S. (2017). Linguistic sign and reading as text creating activity. XLinguae, 10, 2-11.

Lilian, L. (2009). Rainy days - An Alternative Journey from Pride and Prejudice to Passion and Love. Washington: Meryton Press.

Lotman, Yu.M. (2000). Universe of The Mind. Saint Petersburg: Iskusstvo-SPb.

Lotman, Yu.M. (2003). Pushkin. Saint Petersburg: Russia.

McCullough, C. (2008). The Independence of Miss Mary Bennet. New-York: Simon \& Schuster.

Parey, A. (2018). Prequels, Coquels and Sequels in Contemporary Anglophone Fiction. London: Routledge.

Percec, D. (2020). Revisiting the Classics and the New Media Environments: Shakespeare ReTold by Jeanette Winterson, Margaret Atwood and Edward St. Aubyn. In: Multicultural Shakespeare, 20(1), 133-150. DOI:10.18778/2083-8530.20.10

Spirik, J. (2014). Censorship, Indirect Translations and Non-translation: The (Fateful) Adventures of Czech Literature in 20th-century Portugal. Cambridge: Cambridge Scholars Publishing.

Stockwell, P. (2013). The positioned reader. In: Language and Literature, 22(3), 263-277. DOI: $10.1177 / 0963947013489243$

Troost, L. 2001. Greenfield S. Jane Austen in Hollywood. Lexington: The University Press of Kentucky.

Wifall, R. (2010). Introduction: Jane Austen and William Shakespeare Twin icons? In: Shakespeare, 6(4), 403-409.

Witosz, B. (2017). Metatext in the Discourse of the Theory of Text, Stylistics and Pragmalinguistics. In: Forum of Linguistics, Forum Lingwistyczne, pp. 107-112. 